\title{
Prevalence and risk factors of hepatitis B and C viruses among haemodialysis patients in Gaza strip, Palestine
}

\author{
Abed El-kader Y El-Ottol ${ }^{1 *}$, Abdelraouf A Elmanama², Basim M Ayesh ${ }^{3}$
}

\begin{abstract}
Background: The prevalence of hepatitis B virus (HBV) and hepatitis $\mathrm{C}$ virus (HCV) and its associated risk factors among haemodialysis (HD) patients in Gaza strip was investigated using serological and molecular techniques.

Results: The overall prevalence of HBV among the four HD centers was $8.1 \%$. The main risk factors were HD center $(p=0.05)$, history of blood transfusion $(p<0.01)$, and treatment abroad $(p=0.01)$. The overall prevalence of HCV among the four HD centers was 22\%. The main risk factors were HD center $(p<0.01)$, time duration on HD ( $<<$ 0.01 ), history of blood transfusion ( $p<0.01$ ), treatment abroad $(p<0.01)$, and history of blood transfusion abroad $(p<0.01)$. Serum aminotransferases levels decreased in HD patients compared with normal population but still there was a direct association between the activity of liver enzymes and both HBV $(p<0.01)$ and HCV $(p<0.01)$ infection.

Conclusion: The much higher prevalence of Hepatitis viruses among HD patients compared to the normal population of Gaza strip indicates a causative relation between HD and hepatitis viruses transmission. Therefore extremely careful observation of preventive infection control measures is essential to limit Hepatitis viruses' transmission in HD centers.
\end{abstract}

\section{Introduction}

Hepatitis $B$ virus (HBV) and hepatitis $\mathrm{C}$ virus (HCV) infections are important causes of morbidity and mortality among haemodialysis (HD) patients and pose problems in the management of patients in the renal dialysis units, because chronic renal failure patients do not clear these viral infections efficiently [1]. In Arab countries, the prevalence of chronic HBsAg positivity among HD patients ranged from $2 \%$ in Morocco, to $11.8 \%$ in Bahrain [2-5]. Also In Arab countries the prevalence of HCV antibodies among HD patients has been reported to range from $27 \%$ in Lebanon to $75 \%$ in Syria [6-9].

However there are strong indications that studies of HD patients which rely solely on serological screening could underestimate the prevalence of HCV infection. Partial immunesuppression in these patients, resulting in poor antibody response may be a contributing factor

\footnotetext{
* Correspondence: a_elottol@yahoo.com

'Microbiology Department, Central Laboratory, Al-Shifa Hospital, Gaza, Palestine

Full list of author information is available at the end of the article
}

[10]. Such shortcomings could be overcome by determining HCV RNA, which may be required to identify all infected patients [11].

No documented data or previous studies have been reported on the prevalence of hepatitis viruses among HD patients in Palestine and to the best of our knowledge this study is the first to address this issue. Therefore the main objective of this study was to estimate the prevalence of HBV and HCV among HD patients in Gaza strip and address the major risk factors for transmission of these viruses among HD patients.

\section{Materials and methods \\ Patients}

All of the four governmental HD centers of Gaza strip were included in this study, and a total of 246 patients were tested during August to September 2007. The study principles and protocols were submitted and approved by the committee of Helsinki, verbal consent was obtained from each patient after the principle of the
Ciomed Central

C 2010 El-Ottol et al; licensee BioMed Central Ltd. This is an Open Access article distributed under the terms of the Creative Commons Attribution License (http://creativecommons.org/licenses/by/2.0), which permits unrestricted use, distribution, and reproduction in any medium, provided the original work is properly cited. 
study and its possible outcomes were explained to all subjects.

All personal information of the study subjects and result were dealt with in confidentiality. A close ended and multiple choice based questionnaire was completed by the researcher via patient interview to ensure proper data collection and prevent any misunderstanding.

\section{Samples collection}

Two blood samples were collected from each patient, in plain tube, prior to dialysis to prevent the interference of heparin with downstream applications. Serum from the first tube was tested within two hours for ALT, AST, HBsAg, and anti-HCV antibodies. Serum from the second tube was frozen at $-70^{\circ} \mathrm{C}$ in a sterile, DNAse, RNAse free tightly capped tube until used for PCR analysis.

\section{Virology}

For $\mathrm{HBsAg}$ determination, Axsym $\mathrm{HBsAg}$ version 2.0 kit (Abbott, USA) was used, Non reactive samples were considered negative for HBsAg and not tested further, while a reactive sample was retested to confirm the result; a repeatedly reactive sample was considered positive and not further tested.

For anti-HCV antibodies determination, Axsym HCV version 3.0 kit (Abbott, USA) was used. Non reactive samples were considered negative for $\mathrm{HCV}$, while reactive samples were retested to confirm the result and repeatedly reactive samples were considered positive. Serologically positive HCV samples were tested individually by nested RT-PCR technique, while negative samples were pooled in batches of ten and tested by the same technique.

\section{Chemistry}

Serum alanine aminotransferase (ALT) and Serum aspartate aminotransferase (AST) levels were analyzed for all samples by using Diasys, (Germany) reagents, the upper limit of normal for ALT and AST were set at 40 $\mathrm{IU} / \mathrm{ml}$ and $37 \mathrm{IU} / \mathrm{ml}$ respectively [12].

\section{Pooling of Serum Samples}

A pooling strategy was developed and tested in this study, in which ten serum samples from different patients (negative anti-HCV) were pooled together in one tube. Two hundred $\mu \mathrm{l}$ serum from each sample were combined together in a single $2 \mathrm{ml}$ microcentrifuge. The tubes were ultracentrifuged for two hours at $(21,000 \times \mathrm{g})$ and cooling at $4^{\circ} \mathrm{C}$. A pellet was visible and the supernatant was reduced to approximately $150 \mu \mathrm{l}$ by removal of most of the liquid. The pellet was resuspended in the remaining serum and viral RNA was extracted for PCR amplification. The samples of a positive pool were either reanalyzed individually or subdivided into 3 smaller pools.

\section{Molecular screening for HCV RNA}

Viral RNA was extracted from serum samples using the QIAamp viral RNA extraction kit according to the manufacturer recommendation (Qiagen, Germany). Both cDNA synthesis and PCR amplification of the target sequences were performed in a single tube using the one step RT-PCR kit according to the manufacturer instructions (Qiagen, Germany). The primers were designed to specifically bind the $5^{\prime} \mathrm{UTR}$ of the HCV genome that is highly conserved among the different genotypes. Primer sequences were as follows: sense external primer $\quad\left(\mathbf{5}^{\prime}\right.$-CCCTGTGAGGAACTWCTGTCTTCA CGC-3'); antisense external primer (5'-G GTGCACG GTCTACGAGACCT-3'); sense internal primer (5' TCTAGCCATGGC GTTAG TRYGAGTGT-3'); and antisense internal primer (5'-CACTCGCAAGCA CCCTATCA GGCAGT-3', $\mathbf{W}=\mathrm{A}$ or $\mathrm{T}, \mathbf{R}=\mathrm{A}$ or $\mathrm{G}$, $\mathbf{Y}=\mathrm{T}$ or $\mathrm{C})$ [13].

The reactions were carried out in $25 \mu \mathrm{l}$ volumes using $10 \mu \mathrm{l}$ RNA in the presence of $0.6 \mu \mathrm{M}$ of each $\mathrm{HCV}$ external primer, $400 \mu \mathrm{M}$ of each dNTP and 5 units RNase inhibitor. The reaction cycling conditions were: 1 cycle at $50^{\circ} \mathrm{C}$ for 30 minutes, 1 cycle at $95^{\circ} \mathrm{C}$ for $15 \mathrm{~min}$ utes followed by 40 cycles of $95^{\circ} \mathrm{C}$ for one minute, $55^{\circ} \mathrm{C}$ for one minute and $72^{\circ} \mathrm{C}$ for one minute. Finally the reactions were allowed to complete at $72^{\circ} \mathrm{C}$ for $10 \mathrm{~min}$ utes and held at $4^{\circ} \mathrm{C}$.

In all cases a second nested PCR was performed to improve the detection capacity and specificity of the PCR test. The second PCR reactions were carried out in $25 \mu \mathrm{l}$ volumes using $5 \mu \mathrm{l}$ DNA template from $1^{\text {st }}$ PCR in the presence of $1 \times$ PCR master mix (Promega, USA) and $0.4 \mu \mathrm{M}$ of each $\mathrm{HCV}$ internal primers. The reaction cycling conditions were 1 cycle at $95^{\circ} \mathrm{C}$ for 5 minutes, followed by 34 cycles of $95^{\circ} \mathrm{C}$ for one minute, $55^{\circ} \mathrm{C}$ for one minute and $72^{\circ} \mathrm{C}$ for one minute. Finally the reactions were allowed to complete at $72^{\circ} \mathrm{C}$ for 10 minutes and hold at $4^{\circ} \mathrm{C}$.

The products were analyzed by $2 \%$ agarose gel with $100 \mathrm{bp}$ ladder and stained with ethidium bromide. The appearance of a $298 \mathrm{bp}$ and 235 bp bands was considered a positive results for the fist and the second PCR respectively.

\section{Statistical analysis}

The data was collected, summarized, tabulated and analyzed using the statistical package for social sciences (SPSS) V.13 software. Differences in proportions were assessed by a chi-square test and mean comparisons by the $\mathrm{t}$-test, $\mathrm{p}$-value $<0.05$ was considered statistically significant. 


\section{Results}

During the study, 131 patients from Al-Shifa hospital in the center of Gaza City, 30 patients from Shuhada'a AlAqsa Hospital in Dair El-Balah, 52 patients from Nasser hospital in Khan Yunis city, and 34 patients from AbuYousef Al-Najar Hospital in Rafah city were included. From the 246 patients tested, there were 131 male and 115 females. The Patients ages ranged from 6 to 80 years, and the mean age for all patients was 46.7 years with standard deviation $(\mathrm{SD}) \pm 17.5$ years.

The overall prevalence of HBV among HD patients in Gaza strip was found to be $8.1 \%$. The highest percentage was $11.5 \%$ in Al-Shifa hospital, followed by $9.6 \%$ in Nasser hospital, and no cases were detected in both Shuhada'a Al-Aqsa and Abu-Yousef Al-Najar Hospitals.

Analysis of risk factors showed that there was a highly statistically significant relationship between HBV infection and age of the patient $(\mathrm{p}=0.04)$. The mean age for HBV positive patients was $39.2 \pm 14.6$ year, while for HBV negative patients was $47.4 \pm 17.6$ year. Male patients were found to be more susceptible to HBV than female patients $(\mathrm{p}=0.01)$ (Table 1).

Other risk factors with statistically significant relation were, the HD center at which patients were treated $(\mathrm{p}=$ $0.05)$; the number of transfused blood units $(\mathrm{p}<0.01)$; and history of treatment Abroad $(\mathrm{p}=0.01)$ (Table 2). HBV was found to have a strong relationship with ALT and AST levels. HBV positive patients had mean ALT value of $22.4 \pm 20.9 \mathrm{IU} / \mathrm{ml}$ while negative patients $13.4 \pm 11.8 \mathrm{IU} / \mathrm{ml}(\mathrm{p}<0.01)$; Also HBV positive patients had AST mean value of $23.5 \pm 15.3 \mathrm{IU} / \mathrm{ml}$ while negative HBV patients $15.2 \pm 11.2 \mathrm{IU} / \mathrm{ml}(\mathrm{p}<0.01)$ (Table 3).

On the other hand, no statistically significant relationship was found between HBV infection and the level of education $(\mathrm{p}=0.9)$; smoking $(\mathrm{p}=0.51)$ (Table 1$)$; HD duration time $(\mathrm{p}=0.68)$; blood transfusion abroad $(\mathrm{p}=$ $0.7)$; and surgical operation abroad ( $(\mathrm{p}=0.7)$ (Table 2).

The prevalence of anti-HCV was $17.9 \%$. The highest percentage was $26.7 \%$ in Al-Aqsa Hospital; followed by $23.1 \%$ in Nasser hospital, then $18.5 \%$ in Al-Shifa hospital, and $0 \%$ in Al-Najar Hospital (Table 4).The prevalence of HCV RNA was $19.1 \%$. The highest percentage was $36.7 \%$ in Al-Aqsa Hospital, then $23.1 \%$ in Nasser hospital, $18.5 \%$ in Al-Shifa hospital, and $0 \%$ in Al-Najar Hospital (Table 4).

By combining the results of both serological and molecular methods, $22 \%$ of patients were found to be HCV positive. $68.5 \%$ of the positive patient samples were detected by the two methods, $18.5 \%$ of the positive patient samples by nested RT-PCR method alone and $13 \%$ of the positive patient samples by serology method alone (Table 4).

The highest prevalence of $\mathrm{HCV}$ was found at Al-Aqsa Hospital (36.7\%), followed by Nasser hospital (28.8\%), then Al-Shifa hospital (21.5\%), and Al-Najar Hospital $(0 \%)$. Four cases $(1.6 \%)$ were identified as positive for both HBV and HCV, two cases at Al-Shifa center, and the other two cases at Nasser hospital.

For HCV infection a highly statistically significant relationship was found between HCV infection and Education level $(\mathrm{p}<0.01)$. Most patients with HCV were found in the preparatory level $(40.7 \%)$ followed by the Elementary level (20.4\%). Smoker patients appear to be more susceptible to HCV than non smokers $(\mathrm{p}<0.01)$ (Table 1$)$.

Other risk factors for $\mathrm{HCV}$ include $\mathrm{HD}$ centers $(<0.01)$, history of blood transfusion $(\mathrm{p}<0.01)$, history of treatment abroad ( $<<0.01)$, blood transfusion abroad $(\mathrm{p}<0.01)$ and time duration on HD $(\mathrm{p}<0.01)$. The

Table 1 Relationship between HBV and HCV infection and Social factors

\begin{tabular}{|c|c|c|c|c|c|}
\hline \multicolumn{2}{|c|}{ Variable } & \multirow{2}{*}{$\begin{array}{c}\begin{array}{c}\text { HBV } \\
\text { Positive }\end{array} \\
39.2 \pm 14.6\end{array}$} & \multirow{2}{*}{$\begin{array}{c}\begin{array}{c}\text { HBV } \\
\text { Negative }\end{array} \\
47.4 \pm 17.6\end{array}$} & \multirow{2}{*}{$\begin{array}{c}\begin{array}{c}\text { HCV } \\
\text { Positive }\end{array} \\
43.4 \pm 15.5\end{array}$} & \multirow{2}{*}{$\begin{array}{c}\begin{array}{c}\text { HCV } \\
\text { Negative }\end{array} \\
47.6 \pm 17.9\end{array}$} \\
\hline Age & Mean Age & & & & \\
\hline & $p$ Value & & & & \\
\hline \multirow[t]{3}{*}{ Patient Sex } & Male & $16(12.2 \%)$ & $115(87.8 \%)$ & 30 (22.9\%) & $101(77.1 \%)$ \\
\hline & Female & $4(34.8 \%)$ & $111(96.5 \%)$ & $24(20.9 \%)$ & $91(79.1 \%)$ \\
\hline & $p$ Value & & & & \\
\hline \multirow[t]{6}{*}{ Education Level } & Illiterate & $4(6.2 \%)$ & $61(93.8 \%)$ & $7(10.8 \%)$ & $58(89.2 \%)$ \\
\hline & Elementary & $4(8.2 \%)$ & $45(91.8 \%)$ & 11 (22.4\%) & $38(77.6 \%)$ \\
\hline & Prep & $6(10.2 \%)$ & $53(89.8 \%)$ & $22(37.3 \%)$ & $37(62.7 \%)$ \\
\hline & Secondary & $4(7.8 \%)$ & $47(92.2 \%)$ & $7(13.7 \%)$ & $44(86.3 \%)$ \\
\hline & University & $2(9.1 \%)$ & 20 (90.9\%) & $7(31.8 \%)$ & $15(68.2 \%)$ \\
\hline & $p$ value & & & & \\
\hline \multirow[t]{3}{*}{ Smoking } & Yes & $2(12.5 \%)$ & $14(87.5 \%)$ & $8(50 \%)$ & $8(50 \%)$ \\
\hline & No & $18(7.8 \%)$ & $212(92.1 \%)$ & $46(20 \%)$ & $184(80 \%)$ \\
\hline & $p$ Value & & & & \\
\hline
\end{tabular}


Table 2 Relationship between HBV, HCV infection, and factors related to HD

\begin{tabular}{|c|c|c|c|c|c|}
\hline Variable & & $\begin{array}{c}\text { HBV } \\
\text { Positive (\%) }\end{array}$ & $\begin{array}{c}\text { HBV } \\
\text { Negative (\%) }\end{array}$ & $\begin{array}{c}\text { HCV } \\
\text { Positive (\%) }\end{array}$ & $\begin{array}{c}\text { HCV } \\
\text { Negative (\%) }\end{array}$ \\
\hline \multirow[t]{5}{*}{ HD Center } & Al-Shifa & $15(11.5)$ & $115(88.5)$ & $28(21.5)$ & $102(78.5)$ \\
\hline & Al-Aqsa & $0(0)$ & $30(100)$ & $11(36.7)$ & 19 (63.3) \\
\hline & Nasser & $5(9.6)$ & $47(90.4)$ & $15(28.8)$ & $37(71.2)$ \\
\hline & Al-Najar & $0(0)$ & $34(100)$ & $0(0)$ & $34(100)$ \\
\hline & $\mathrm{p}$ Value & \multicolumn{2}{|c|}{0.05} & \multicolumn{2}{|c|}{$<0.01$} \\
\hline \multirow[t]{2}{*}{ Time Duration on HD (month) } & Mean Time & 37.7 & 34.3 & 49.6 & 30.3 \\
\hline & $p$ value & \multicolumn{2}{|c|}{0.68} & \multicolumn{2}{|c|}{$<0.01$} \\
\hline \multirow[t]{6}{*}{ Number of Blood Units Transfused } & 0 & $7(6.8)$ & $96(93.2)$ & $19(18.4)$ & $84(81.6)$ \\
\hline & $1-5$ & $4(6.7)$ & 56 (93.3) & $6(10)$ & $54(90)$ \\
\hline & $5-10$ & $2(4.4)$ & 43 (95.6) & $9(20)$ & $36(80)$ \\
\hline & $10-15$ & $1(5)$ & $19(95)$ & $10(50)$ & $10(50)$ \\
\hline & $<15$ & $6(33.3)$ & $12(66.7)$ & $10(55.6)$ & $8(44.4)$ \\
\hline & $p$ value & \multicolumn{2}{|c|}{$<0.01$} & \multicolumn{2}{|c|}{$<0.01$} \\
\hline \multirow[t]{3}{*}{ Number of Patients Treated Abroad } & Yes & $18(11.8)$ & $134(88.2)$ & $45(29.6)$ & $107(70.4)$ \\
\hline & No & $2(2.1)$ & $92(97.8)$ & $9(9.6)$ & $85(90.4)$ \\
\hline & $p$ value & \multicolumn{2}{|c|}{0.01} & \multicolumn{2}{|c|}{$<0.01$} \\
\hline \multirow[t]{3}{*}{ Surgical Operation Abroad from the152 patients treated abroad } & yes & $14(11.5)$ & $108(88.5)$ & $36(29.5)$ & $86(70.5)$ \\
\hline & no & $4(13.3)$ & $26(86.7)$ & $9(30)$ & $21(70)$ \\
\hline & $\mathrm{p}$ value & \multicolumn{2}{|c|}{0.7} & \multicolumn{2}{|c|}{0.95} \\
\hline \multirow[t]{3}{*}{ Blood Transfusion Abroad from the 152 patients treated abroad } & yes & $9(12.9)$ & $61(87.1)$ & $29(41.4)$ & 41 (58.6) \\
\hline & no & $9(11)$ & $73(89)$ & 16 (19.5) & $66(80.5)$ \\
\hline & $p$ value & \multicolumn{2}{|c|}{0.70} & \multicolumn{2}{|c|}{$<0.01$} \\
\hline
\end{tabular}

mean time duration for HCV negative patients was $30.3 \pm 33.7$ months while for positive $\mathrm{HCV}$ was $49.6 \pm$ 42.4 month; (Table 2).

$\mathrm{HCV}$ also was found to have a strong relationship with ALT and AST levels, Positive HCV patients have mean ALT value of $19.9 \pm 19.1 \mathrm{IU} / \mathrm{ml}$ while negative $\mathrm{HCV}$ patients has ALT mean value of $12.53 \pm 10.3 \mathrm{IU} /$ $\mathrm{ml}(\mathrm{p}<0.01)$. Also positive $\mathrm{HCV}$ patients had AST mean value of $22.9 \pm 16.9 \mathrm{IU} / \mathrm{ml}$ while negative $\mathrm{HCV}$ patients has AST mean value of $13.9 \pm 9.00 \mathrm{IU} / \mathrm{ml}$ $(\mathrm{p}<0.01)$ (Table 3$)$.

No statistically significant relationship was found between HCV and patient sex $(\mathrm{p}=0.70)$ and age $(\mathrm{p}=$ 0.11 ) (Table 1$)$, and surgical operation abroad (p-0.95) (Table 2).

\section{Discussion}

Viral hepatitis remains a major hazard for both patients and medical staff of HD units [14]. In this study, the overall prevalence of HBV in HD patients in Gaza strip was $8.1 \%$. This prevalence higher than in other neighboring countries like Jordan (5.9\%) and lower than others such as Saudi Arabia (10\%) and Bahrain $(11.8 \%)$ [3-5].

Statistically significant differences in prevalence between the four HD centers are obvious ( $p=0.05)$. Such a result was also observed in a previously published research in Jordan [3]. This difference in prevalence may be due to variation in the degree of implementation of the universal precautions to prevent nosocomial transmission.

Table 3 Relationship between HBV, HCV infection and liver enzymes among HD patients

\begin{tabular}{|c|c|c|c|c|c|}
\hline \multirow[t]{5}{*}{ Liver Enzymes } & & HBV Positive & HBV Negative & HCV Positive & HCV Negative \\
\hline & ALT mean & 22.4 & 13.4 & 19.9 & 12.5 \\
\hline & $p$ Value & & & & \\
\hline & $\overline{\text { AST mean }}$ & 23.5 & 15.2 & 22.9 & 13.9 \\
\hline & $\mathrm{p}$ Value & & & & \\
\hline
\end{tabular}


Table 4 Overall prevalence of HCV among HD patients in Gaza Strip

\begin{tabular}{llcc}
\hline Character & $\begin{array}{c}\text { HCV RNA } \\
\text { positive }\end{array}$ & $\begin{array}{c}\text { HCV RNA } \\
\text { negative }\end{array}$ & Total \\
\hline anti- HCV positive & $37(15 \%)$ & $7(2.8 \%)$ & $44(17.9 \%)$ \\
\hline $\begin{array}{l}\text { anti- HCV } \\
\text { negative }\end{array}$ & $10(4.1 \%)$ & $192(78 \%)$ & $\begin{array}{c}202 \\
(82.1 \%)\end{array}$ \\
\hline Total & $47(19.1 \%)$ & $199(80.9 \%)$ & $246(100 \%)$ \\
\hline
\end{tabular}

In our study no statistically significant relationship was found between $\mathrm{HBV}$ and duration on HD, this observation was in agreement with a previous report in Moldavia [15], and in disagreement with another in Jordan [3] In our study, the prevalence of HBV was increased significantly with increasing the number of blood units transfused $(\mathrm{p}<0.01)$, This is in agreement with a previous study in Brazil [16], while another study in Jordan showed no relationship [3].

In general, most patients of Gaza strip with chronic diseases or who are in need for major surgeries are treated abroad. Also some patients during their treatment undergo HD. We found a statistically significant relationship between treatment abroad and HBV infection $(p=0.01)$. A previous study in India showed that traveling abroad is associated with increased risk of hepatitis virus infection and this risk is expected to be increased when traveling to endemic areas [17].

No statistically significant relationship was found between HBV prevalence and surgical operation or blood transfusion abroad. This result contradicts results from a previous work in Brazil that showed that surgery is a risk factor for acquiring hepatitis infection in the general population [18]. This contradiction may be due to differences in the type of surgery, the level of medical services and other factors related to the countries were surgeries are performed.

A statistically significant relationship was found between HBV infection and age of the patients, as patients less than 40 years old were found more susceptible to HBV than older patients. This is in agreement with a study done in Gaza among the general population, which found that the highest percentage of HBsAg among age group of 30 to 39 years [19]. The results also showed that male HD patients had higher HBV prevalence than females. This may be related to the fact that males in Palestine are more socially active than female. Furthermore, they are more exposed to male-related risk factors for HBV than female (e.g. hairdressing and circumcision). This result is in agreement with study in general population of Lebnon [20].

The prevalence of anti-HCV among HD patients was $17.9 \%$, This anti-HCV prevalence was lower than Tunisia (19.1\%), Lebanon (27\%), Jordan (34.6\%), and Syria
(75\%) $[21,6,7,9]$. Partial immunosuppression in HD patients resulting in a poor antibody response to Hepatitis viruses' infection [10] makes serological screening of HCV underestimate. Such short coming could be overcome by detecting HCV RNA [11].

In this study HCV RNA was detected in $19.1 \%$ of HD patients, this result is lower than some countries such as Brazil (30.6\%) and Greece (31.7\%) [22,23]. HCV RNA was detected in only $84.1 \%$ of the anti-HCV positive patients. This deviation between PCR and ELISA results was also previously reported in many studies like in Syria (87.5\%), Jordan (30.6\%), and Tunisia $(72.3 \%)[9,7,16]$. The possible explanations for this Difference in percentage of viraemic patients includes false positive serology, intermittent viraemia, or the level of viraemia in is below the lower limit of PCR detection [7]. Also the viral load is relatively low in this group of patients and long term maintenance HD decreases the HCV RNA level but doesn't produce clearance of viraemia [24].

On the other hand, HCV RNA was detected in serum of 10 patients of the anti-HCV negative (4.95\%). Again, several studies have shown that serological assays alone are not sufficient for diagnosis of HCV infection and the detection of HCV RNA is required to identify all infected patients [25]. So detection of HCV RNA is more reliable than serology in detecting ongoing $\mathrm{HCV}$ infection in HD patients who may not mount an adequate antibody response [25]. Our results among seronegative patients were higher than studies in center of Recife, Brazil (0\%) [26], but lower than another study in central Brazil (10.3\%) [27]. The overall prevalence of HCV among Gazian HD patients thus is (22\%). This is higher than in Germany in which the overall prevalence was (3\%) [28] and lower than in Brazil (46.7\%) [29].

HCV prevalence was different between HD centers, and as stated earlier, this difference in prevalence may be due to different degrees of commitment to universal precautions taken in each center, the same result was shown in previous studies in Jordan and Tunisia [7,21].

Duration on HD was found to be a statistically significant risk factor for HCV infection in HD setting. The risk of $\mathrm{HCV}$ infection increased with increasing the time duration. In HD population under investigation, other studies from different regions in the world have shown similar results [30].

This effect may be due to nosocomial transmission of $\mathrm{HCV}$ as indicated by other studies, epidemiological and molecular studies have shown the role of HD environment for dissemination of $\mathrm{HCV}$ between patients [31,32]. Actually in our study it was not unusual to find staff taking care of susceptible and infected patients in the same shift. Additionally they didn't routinely discard gloves after use; this practice may facilitate the dissemination of HCV RNA between HD patients. 
Blood transfusion was found to be a highly statistically significant risk factor in this study. The risk increased with the increase in the number of blood units which were transfused $(\mathrm{p}<0.01)$. This result was in agreement with other study in USA[33].

No relationship was found between HCV prevalence and sex of the patients, this was in agreement with other studies [34]. Also no statistically significant relationship was found between HCV prevalence and patient's age; this finding is supported by other study [34].

A direct statistically significant relationship was found between HCV and education level in which most of $\mathrm{HCV}$ positive patients were in the preparatory level followed by elementary. Previous studies among general population worldwide showed that $\mathrm{HCV}$ is prevalent among less educated level people [35].

In this study a direct relationship was found between $\mathrm{HCV}$ prevalence and smoking, in which smoker patients are more susceptible to HCV than non smokers. This may be due to bad practices in Gaza strip where people are smoking water pipe (Shisha) in groups. Water pipe is passed from one person to another; the mouth piece maybe wiped but is not changed between users, which theoretically result in exposure to blood from individuals with gingivitis for example; Also smokers are highly associated with increased visit to outpatient physician and hospital services, a result that was indicated in reports among general population.

The striking difference in prevalence and risk factors seen between HBV and HCV, with similar molecular size and transmission routes in general and the HD population, was also described by others [36].

Co-infection with both $\mathrm{HBV}$ and $\mathrm{HCV}$ was reported in 4 patients $(1.6 \%)$ of the total HD population which is low when compared with other study in Moldavia [15].

In our study a direct and strong association between the activity of liver enzymes and both HBV and HCV prevalence was found. Previous studies suggested that ALT levels, even that not exceeding upper limit of normal are higher in anti-HCV positive patients in comparison with anti-HCV negative patients $[37,38]$. Therefore recriteria for normal reference of ALT and AST is proposed for HD population. On the other hand, other study suggested that serum aminotransferases aren't reliable marker for HCV screening or for evaluation of hepatitis activity in HD patients since they are frequently normal [39].

\section{Conclusion}

Hepatitis B and C viruses' infection are very frequent among HD patients in Gaza strip as in many regions of the world. The HD center, blood transfusion and treatment abroad appear to be the major risk factors for both viruses.
For HBV infection other risk factors included, younger age and male patients. Further studies among total population are needed to investigate this factor. For $\mathrm{HCV}$ other risk factors for infection include, the duration on HD, smoking, and the level of education.

The much higher prevalence of Hepatitis viruses among HD patients compared to the normal population of Gaza strip indicates a causative relation between HD and hepatitis viruses transmission.

Therefore extremely careful observation of preventive infection control measures is essential to limit Hepatitis viruses' transmission in HD centers.

\section{Acknowledgements}

The authors express their sincere thanks for Islamic University-Gaza (IUG) and the Arab Palestinian Investment Co. Ltd. (APIC), staff of virology and clinical chemistry department at Alshifa hospital, all workers and patients at the haemodialysis centers, and to molecular biology department team at Shuhada'a Al-Remal central laboratory for all their helpful and friendly support to complete this work.

\section{Author details}

${ }^{1}$ Microbiology Department, Central Laboratory, Al-Shifa Hospital, Gaza, Palestine. ${ }^{2}$ Medical Technology Department, Islamic University, Gaza, Palestine. ${ }^{3}$ Biology Department, Al-Aqsa University, Gaza, Palestine.

\section{Authors' contributions}

AYO participated in the design of the study; carried out and personally financed the studies; performed the statistical analysis; and drafted the manuscript. AAM participated in the design of the study; supervision on the theoretical and practical work. BMA participated in the design of the study; and supervised on the molecular genetic studies and the statistical analysis. All authors have read and approved the final manuscript.

\section{Competing interests}

The authors declare that they have no competing interests.

Received: 12 June 2010 Accepted: 1 September 2010

Published: 1 September 2010

\section{References}

1. Saha D, Agarwal SK: Hepatitis and HIV infection during haemodialysis. J Indian Med Assoc 2001, 99(4):194-199, 203,213.

2. Boulaajaj K, Elomari Y, Elmaliki B, Madkouri B, Zaid D, Benchemsi N: Prevalence of hepatitis $C$, hepatitis $B$ and HIV infection among haemodialysis patients in Ibn-Rochd university hospital, Casablanca. Nephrol Ther 2005, 1(5):274-284.

3. Al Hijazat M, Ajlouni Y: Hepatitis B infection among patients receiving chronic hemodialysis at the royal medical services in Jordan. Saudi J Kidney Dis Transpl 2008, 19(2):260-267.

4. Khan LA, Khan SA: Prevalence of hepatitis $B$ and $C$ markers in patients on maintenance hemodialysis in Najran. Saudi Med J 2001, 22(7):641-642.

5. Almawi WY, Qadi AA, Tamim H, Ameen G, Bu-Ali A, Arrayid S, Abou Jaoude MM: Seroprevalence of hepatitis $C$ virus and hepatitis $B$ virus among dialysis patients in Bahrain and Saudi Arabia. Transplant Proc 2004, 36(6):1824-1826.

6. Naman RE, Mansour I, Klayme S, Khalil G: Hepatitis C virus in hemodialysis patients and blood donors in Lebanon. J Med Liban 1996, 44(1):4-9.

7. Bdour S: Hepatitis $C$ virus infection in Jordanian haemodialysis units: serological diagnosis and genotyping. J Med Microbiol 2002, 51(8):700-704.

8. Hachicha J, Hammami A, Masmoudi H, Ben Hmida M, Karray H, Kharrat M, Kammoun $F$, Jarraya A: Viral hepatitis $C$ in chronic hemodialysis patients in southern Tunisia, prevalence and risk factor. Ann Med Interne 1995, 146(5):295-298.

9. Abdulkarim AS, Zein NN, Germer JJ, Kolbert CP, Kabbani L, Krajnik KL, Hola A, Agha MN, Tourogman M, Persing DH: Hepatitis C virus genotype 
and hepatitis $G$ virus in hemodialysis patients from Syria: identification of two novel hepatitis C virus subtypes. Am J Trop Med Hyg 1998, 59(4):571-576.

10. Goldbloom SE, Reed WP: Host defenses and immunologic alterations associated with chronic hemodialysis. Ann Intern Med 1980, 93(4):597-613.

11. Fabrizi F, Martin P, Dixit V, Brezina M, Russell J, Conrad A, Schmid P, Gerosa S, Gitnick G: Detection of de novo hepatitis $C$ virus infection by polymerase chain reaction in hemodialysis patients. Am J Nephrol 1999, 19(3):383-388.

12. Ministry Of Health: Palestinian clinical laboratory tests guide. MOH 2005.

13. Stuyver L, Rossau R, Wyseur A, Duhamel M, Vanderborght B, Van Heuverswyn H, Maertens G: Typing of hepatitis $C$ virus isolates and characterization of new subtypes using a line probe assay. $J$ Gen Virol 1993, 74(pt 6):1093-1102.

14. Feher T, Ambuhi PM: Chronic hepatitis virus infections in patients on renal replacement therapy. Nephrol Dial Transplant 2004, 19(5):1049-1053.

15. Covic A, lancu L, Apetrei C, Scripcaru D, Volovat C, Mititiuc I, Covic M: Hepatits virus infection in haemodialysis patients from Moldavia. Nephrol Dial Transplant 1999, 14(1):40-45.

16. Busek SU, Babá EH, Tavares Filho HA, Pimenta L, Salomão A, CorrêaOliveira R, Oliveira GC: Hepatitis C and Hepatitis B Virus Infection in Different Hemodialysis Units in Belo Horizonte, Minas Gerais, Brazil. Mem Inst Oswaldo Cruz 2002, 97(6):775-778.

17. Jauréguiberry $S$, Grandière-Pérez $L$, Ansart $S$, Laklache $H$, Métivier $S$, Caumes E: Acute hepatitis C virus infection after a travel in India. J Travel Med 2005, 12(1):55-56.

18. Busek S, Oliveira G: Molecular epidemiology of the hepatitis C virus in Brazil. Genet Mol Res 2003, 2(1):117-123.

19. Yassin K, Awad R, Tebi AJ, Queder A, Laaser U: Prevalence and risk factors of HBsAg in Gaza: Implications for prevention and control. J Infect 2002, 44(4):252-256.

20. Kalaajieh W, Deeaoui M, Chbani-Rima A: Epidemiology of acute hepatitis B infection in Lebnon. Med Mal Infect 2002, 32(7):382-386.

21. Ayed K, Gorgi Y, Ben Abdallah T, Aouadi H, Jendoubi-Ayed S, Sfar I, Makni $\mathrm{H}$ : Hepatitis $\mathrm{C}$ virus infection in hemodialysis patients from Tunisia: national survey by serologic and molecular methods. Transplant Proc 2003, 35(7):2573-2575

22. Carneiro MA, Martins RM, Teles SA, Silva SA, Lopes CL, Cardoso DD, Vanderborght BO, Yoshida CF: Hepatitis C prevalence and risk factors in hemodialysis patients in central Brazil: a survey by polymerase chain reaction and serological methods. Mem Inst Oswaldo Cruz 2001, 96(6):765-769

23. Rigopoulou El, Stefanidis I, Liaskos C, Zervou EK, Rizos C, Mina P, Zachou K, Syrganis C, Patsidis E, Kyriakopoulos G, Sdrakas L, Tsianas N, Dalekos GN: HCV RNA qualitative assay based on transcription mediated amplification improves the detection of hepatitis $C$ virus infection in patients on hemodialysis: Results from five hemodialysis units in central Greece. J Clin Virol 2005, 34(1):81-85.

24. Furusyo N, Hayashi J, Ariyama I, Sawayama Y, Etoh Y, Shigematsu M Kashiwagi S: Maintenance hemodialysis decreases serum hepatitis $C$ virus (HCV) RNA levels in hemodialysis patients with chronic HCV infection. Am J Gastroenterol 2000, 95(2):490-496.

25. Bukh J, Wantzin P, Krogsgaard K, Knudsen F, Purcell RH, Miller RH: High prevalence of hepatitis $\mathrm{C}$ virus (HCV) RNA in dialysis patients: failure of commercially available antibody tests to identify a signiticant number of patients with HCV infection. J Infect Dis 1993, 168(6):1343-1348.

26. Albuquerque AC, Coêlho MR, Lopes EP, Lemos MF, Moreira RC: Prevalence and risk factors of hepatitis $C$ virus infection in hemodialysis patients from one center in Recife, Brazi. Mem Inst Oswaldo Cruz-Rio de Janeiro 2005, 100(5):467-470

27. Carneiro MA, Martins RM, Teles SA, Silva SA, Lopes CL, Cardoso DD, Vanderborght BO, Yoshida CF: Hepatitis C prevalence and risk factors in hemodialysis patients in central Brazil: a survey by polymerase chain reaction and serological methods. Mem Inst Oswaldo Cruz 2001, 96(6):765-769.

28. Hinrichsen H, Leimenstoll G, Stegen G, Schrader H, Fölsch UR, Schmidt WE, PHV Study Group: Prevalence and risk factors of hepatitis $C$ virus infection in haemodialysis patients: a multicentre study in 2796 patients. Gut 2002, 51(3):429-433.
29. Reddy GA, Dakshinamurthy KV, Neelaprasad P, Gangadhar T, Lakshmi V: Prevelance of HBV and HCV dual infection in patients on hemodialysis. Indian J Med Microbiol 2005, 23(1):41-43,

30. Irish DN, Blake C, Christophers J, Craske JE, Burnapp L, Abbs IC, MacMahon EM, Muir P, Banatvala JE, Simmonds P: Identification of hepatitis $C$ seroconversion resulting from nosocomial transmission on a haemodiolysis unit: implications for infection control and laboratory screening. J Med Virol 1999, 59(2):135-140.

31. Allander T, Gruber A, Naghavi M, Beyene A, Söderström T, Björkholm M, Grillner L, Persson MA: Frequent patient to patient transmission of hepatitis C virus in a haematology ward. Lancet 1995, 345(8950):603-607

32. Sartor C, Brunet $P$, Simon S, Tamalet C, Berland Y, Drancourt M: Transmission of hepatitis $C$ virus between hemodialysis patients sharing the same machine. Infect Control Hosp Epidemiol 2004, 25(7):609-611.

33. de Medina M, Ashby M, Schlüter V, Hill M, Leclerq B, Pennell JP, Jeffers $L$, Reddy KR, Schiff ER, Hess G, Perez GO: Prevalence of hepatitis C and G virus infection in chronic hemidialysis patients. Am J Kidney Dis 1998, 31(2):224-226.

34. Lopes EP, Gouveia EC, Albuquerque AC, Sette LH, Mello LA, Moreira RC, Coelho MR: Determination of the cut off value of serum alanine aminotransferase in patients undergoing hemodialysis, to identify biochemical activity in patients with hepatitis C viraemia. I clin Viro 2006, 35(3):298-302.

35. el-Sadawy M, Ragab H, el-Toukhy H, el-Mor Ael-L, Mangoud AM, Eissa MH, Afefy AF, el-Shorbagy E, Ibrahem IA, Mahrous S, Abdel-Monem A, Sabee El, Ismail A, Morsy TA, Etewa S, Nor Edin E, Mostafa Y, Abouel-Magd Y, Hassan MI, Lakouz K, Abdel-Aziz K, el-Hady G, Saber M: Hepatitis C virus infection at Sharkia Governorate, Egypt: seroprevalence and associated risk factors. J Egypt Soc Parasitol 2004, 34(1 Suppl):367-384.

36. Dussol $B$, Berthezène $P$, Brunet $P$, Roubicek $C$, Berland $Y$ : Hepatits $C$ virus among chronic dialysis patients in the south of France: a collaborative study. Am J Kidney Dis 1995, 25(3):399-404.

37. Fabrizi F, Lunghi G, Finazzi S, Colucci P, Pagano A, Ponticelli C, Locatelli F: Decreased serum aminotransferase activity in patients with chronic renal failure: impact on the detection of viral hepatitis. Am J Kidney Dis 2001, 38(5):1009-1015.

38. Gouveia EC, Lopes EP, Moura I, Cruz M, Kosminsky L, Pernambuco JR: Identification of the cut-off value for serum alanine aminotransferase in hepatitis $C$ screening of patients with chronic renal failure on hemodialysis. Rev Soc Braz Med Trop 2004, 37(1):18-21.

39. Fabrizi F, Poordad F, Martin P: Hepatitis C infection and the patients with end-stage renal disease. Hepat 2002, 36(1):3-10

doi:10.1186/1743-422X-7-210

Cite this article as: El-Ottol et al:: Prevalence and risk factors of hepatitis $\mathrm{B}$ and $\mathrm{C}$ viruses among haemodialysis patients in Gaza strip, Palestine. Virology Journal 2010 7:210.

\section{Submit your next manuscript to BioMed Central and take full advantage of:}

- Convenient online submission

- Thorough peer review

- No space constraints or color figure charges

- Immediate publication on acceptance

- Inclusion in PubMed, CAS, Scopus and Google Scholar

- Research which is freely available for redistribution

Submit your manuscript at www.biomedcentral.com/submit
C Biomed Central 